\title{
DIRECT EVIDENCE FOR THE OXIDATION OF FREE FATTY ACIDS BY PERIPHERAL TISSUES *
}

\author{
By SAMUEL J. FRIEDBERG and E. HARVEY ESTES, JR.
}

(From the Central Reference Laboratory and Radioisotope Unit, Veterans Administration Hospital, and the Department of Medicine, Duke University Medical Center, Durham, N.C.)

(Submitted for publication September 11, 1961 ; accepted November 30, 1961)

Since the recognition of the importance of the role of plasma free fatty acids (FFA) in the metabolism of lipids $(1,2)$, a number of studies has suggested that plasma FFA is a major substrate for the energy metabolism of tissues. Fredrickson and Gordon (3) found that $\mathrm{C}^{14} \mathrm{O}_{2}$ was excreted after intravenous administration of albumin-bound $\mathrm{C}^{14}$-carboxyl-labeled fatty acids. It was later shown that exercise increases the turnover rate of plasma FFA (4) and might play an important role in FFA mobilization $(5,6)$. Unpublished studies by Fredrickson, repeated in this laboratory, have shown that exercise can increase $\mathrm{C}^{14} \mathrm{O}_{2}$ excretion rate sixfold or more. Together with this increased $\mathrm{C}^{14} \mathrm{O}_{2}$ excretion, there is an approximately equal increase in both the volume of expired air and the total $\mathrm{CO}_{2}$ so that the specific activity of $\mathrm{C}^{14} \mathrm{O}_{2}$ remains unchanged. More recent studies (7) have shown that the forearm extracts from 10 to 50 per cent of the plasma FFA flowing through it. Bragdon and Gordon (8), and Laurell (9) have shown that adipose tissue in the fasting rat competes poorly with other sites for uptake of injected radiopalmitate. It is therefore assumed that the radiopalmitate circulating through the arm is taken up primarily by muscle and perhaps also by skin.

Although FFA disappear upon passage through the forearm, and $\mathrm{C}^{14} \mathrm{O}_{2}$ appears in expired air, these facts do not necessarily imply that the oxi-

* This investigation was supported in part by a grant from the Life Insurance Medical Research Fund; by a research grant, $\mathrm{H}-4807$; a training grant, $\mathrm{HTS}-5369$, from the National Heart Institute, Public Health Service; a research grant, A-4535-MET, from the National Institutes of Health, Public Health Service; a research grant for July 1960-1961, from the North Carolina Heart Association; a research grant, A-5509, Physiol. Chem., from the National Institutes of Health, Public Health Service; and by the Regional Center for the Study of Aging, Duke University. dation actually occurs within the peripheral tissues; the studies mentioned do not rule out the possibility that an intermediate metabolic product from FFA breakdown, such as acetoacetate or $\beta$-hydroxybutyrate, may be delivered to the circulation from some organ such as the liver before final oxidation by other tissues to carbon dioxide.

On the basis of the information mentioned above, namely, that forearm removes a considerable fraction of FFA circulating through it, one would expect that a large fraction of radiopalmitate injected directly into the brachial artery would be retained by the forearm, and that the rest would be distributed, greatly diluted by the blood, to the other body tissues. If, as has been postulated, the forearm muscle does in fact oxidize the radiopalmitate, one would anticipate the presence of a much greater amount of $\mathrm{C}^{14} \mathrm{O}_{2}$ in the venous blood issuing from the injected forearm than from the opposite one.

\section{METHODS}

A simple apparatus was designed to liberate $\mathrm{C}^{14} \mathrm{O}_{2}$ from blood samples and trap it in Hyamine (see Figure 1). Ten-, 15-, or 20-ml samples of blood, representing approximately a minute's forearm blood circulation, were introduced into the reaction flask beneath $4 \mathrm{ml}$ of mineral oil and the flask was clamped to the manifold. Five $\mathrm{ml}$ of $0.5 \mathrm{M}$ Hyamine hydroxide was pipetted into the $10-\mathrm{ml}$ graduated cylinder used as the $\mathrm{CO}_{2}$ trap (10). Twenty $\mathrm{ml}$ of concentrated lactic acid was then introduced into the reaction flask from the reservoir with pressure from a rubber bulb and the reservoir stopcock closed before emptying the reservoir completely. The nitrogen flow was then carefully turned on and the rate regulated so that the Hyamine was not splashed out of the $10-\mathrm{ml}$ graduated cylinder. The nitrogen gas carrier agitated the blood and carried the $\mathrm{CO}_{2}$ into the Hyamine. A dry ice and acetone trap was interposed to remove water vapor. It was essential to keep the diameter of the " $U$ " tube small to reduce dead space in the apparatus. After the nitrogen flow was begun, the flask was continuously agitated for at least 25 minutes by means of a mechanical 
TABLE I

Per cent $\mathrm{C}^{14} \mathrm{O}_{2}$ trapped following reaction of $0.1 \mu \mathrm{c} \mathrm{Na} \mathrm{C}^{14} \mathrm{O}_{3}$

\begin{tabular}{rcc}
\hline & Activity & Recovered \\
\hline & $d p m$ & $\%$ \\
1 & 20,200 & 91.7 \\
2 & 20,000 & 90.8 \\
3 & 20,200 & 91.8 \\
4 & 20,800 & 94.7 \\
5 & 20,200 & 92.0 \\
6 & 20,000 & 91.0 \\
7 & 20,200 & 92.0 \\
8 & 21,500 & 98.0 \\
9 & 21,300 & 97.0 \\
10 & 21,400 & 97.3 \\
11 & 21,300 & 97.0 \\
\hline
\end{tabular}

wrist action shaker. The completeness of the recovery of the $\mathrm{CO}_{2}$ by this system depended on the adequacy of shaking and on the volume of gas bubbled through the reaction flask. After the reaction was complete, the stainless steel cannula dipping into the Hyamine was lifted just above the level of fluid. The Hyamine solution remaining on the tip of the cannula was rinsed into the cylinder with methanol, and the volume of the Hyamine was brought back to the $5 \mathrm{ml}$ mark. A 2-ml aliquot of the Hyamine solution was then pipetted into a liquid scintillator vial with $15 \mathrm{ml}$ of phosphor solution and counted in a Packard Tri-Carb liquid scintillation spectrometer.

The system was tested by means of old bank blood to which was added $1 \mathrm{ml}$ of $\mathrm{Na}_{2} \mathrm{C}^{14} \mathrm{O}_{3}$ solution with activity of $21,900 \mathrm{dpm}$ per $\mathrm{ml}$ of solution. The exact activity was determined by means of a benzoic acid- $\mathrm{C}^{\mathbf{1 4}}$ internal standard. The activity of the Hyamine $\mathrm{C}^{14} \mathrm{O}_{2}$ complex obtained after recovery was determined with the same internal standard. Table I shows the results of the recovery studies. Any contamination of the trapping me-

TABLE II

Data on extent of contamination of Hyamine trapping medium in 10 consecutive determinations without cleaning apparatus*

\begin{tabular}{rcc}
\hline \hline & $\begin{array}{c}\text { Activity from } \\
\text { radiopalmitate } \\
\text { recovered in } \\
\text { Hyamine }\end{array}$ & $\begin{array}{c}\text { Radiopalmitate } \\
\text { activity in re- } \\
\text { action flask } \\
\text { recovered in } \\
\text { Hyamine }\end{array}$ \\
1 & $d p m$ & $\%$ \\
2 & 0 & 0 \\
3 & 181 & 0.0165 \\
4 & 133 & 0.0121 \\
5 & 379 & 0.0345 \\
6 & 451 & 0.0409 \\
7 & 549 & 0.0499 \\
8 & 352 & 0.0320 \\
9 & 681 & 0.0618 \\
10 & 1,127 & 0.102 \\
& 1,117 & 0.101 \\
\hline
\end{tabular}

* Palmitic acid-1- $\mathrm{C}^{14}, 0.5 \mu \mathrm{c}$, added to reaction flask in each of the 10 determinations. dium by radioactivity other than $\mathrm{C}^{14} \mathrm{O}_{2}$ occurring by use of the present method was evaluated. In order to do this $0.5-\mu \mathrm{c}$ aliquots of prepared albumin-bound radiopalmitate were added to $20 \mathrm{ml}$ of old bank blood and allowed to react as described above. Table II shows that a maximum of $1,127 \mathrm{dpm}$ from contaminating radiopalmitate or its possible degradation products appeared in the Hyamine. This figure represents 0.1 per cent of the added radiopalmitate. The data were obtained from ten consecutive runs without cleaning any of the assembly except the reaction flask. The increasing amount of recovered activity probably represents cumulative contamination of the apparatus from repeated additions of radiopalmitate. If a $20-\mathrm{ml}$ blood sample were to contain as many as 20,000 non- $\mathrm{C}^{14} \mathrm{O}_{2}$ dpm after injection of $4.5 \mu \mathrm{c}$ of radiopalmitate, the Hyamine might therefore contain $20 \mathrm{dpm}$ of unwanted radioactivity, a negligible quantity.

\section{EXPERIMENTAL}

Healthy young male volunteers between the ages of 21 and 25 years were selected. After a 14-hour overnight fast, indwelling arterial needles were placed in a brachial artery and in an antecubital vein of the experimental arm, and another needle was placed in an antecubital vein of the opposite arm. Veins were selected which were thought to drain primarily the deeper forearm tissues. The hand circulation of the experimental arm was temporarily occluded with a pediatric blood pressure cuff and $4.5 \mu \mathrm{c}$ of albumin-bound palmitic acid-1- $\mathrm{C}^{14}$, prepared as previously described (4), was injected into the brachial artery over a period of 3 to 5 minutes. ${ }^{1}$ The purpose of the occlusive wrist cuff was to shunt the injected label into forearm tissues rather than through the metabolically inactive but highly vascularized regions of the hand. Blood was flushed back and forth a few times through the needle and the hub washed with saline to clear residual radioactivity. Over approximately the next hour, simultaneously drawn 22-ml blood samples were collected four times from each of the three indwelling needles. The intervals of time selected differed in the several experiments and are recorded in Tables III, IV, and V. Before collection of each sample, the wrist circulation was occluded in both arms in order to collect forearm venous blood without admixture from hand venous blood. Drawing of samples was preceded by bilateral application of arm tourniquets to facilitate drawing of venous samples. The experimental arrangement, then, was to produce a high uptake of radiopalmitate in the injected arm. The preponderance of activity which would escape from the arm would then rapidly mix with the whole blood volume and would be delivered greatly diluted to the rest of the body.

The effect of exercise was studied by having the subject squeeze two identical rubber sphygmomanometer

${ }^{1}$ Palmitic acid-1-C $\mathrm{C}^{\mathbf{1 4}}$ obtained from Nuclear-Chicago Corporation. This material, when converted to the methyl ester, gave a single peak by gas liquid chromatography. 
bulbs, one in each hand, for 1 minute, at the rate of 80 squeezes per minute timed by a metronome. The wrist cuffs were then applied and the subject continued to exercise for another 30 seconds before samples were taken. Blood was then drawn while the subject continued to exercise. In later studies, when it became clear that $\mathrm{C}^{14} \mathrm{O}_{2}$ activity in the control vein was not significantly different from that of the artery, blood was drawn only from the experimental arm.

An estimate of the magnitude of blood flow increase produced by this amount of exercise was made in one subject by means of a venous occlusion plethysmograph. It was found that flow rose from a resting value of 1.17 to $1.56 \mathrm{ml}$ per $100 \mathrm{ml}$ of forearm tissue per minute to $15.9 \mathrm{ml}$ per minute immediately after exercise.

\section{RESULTS}

The results in all cases (Tables III and IV) show a negative arteriovenous difference of labeled $\mathrm{CO}_{2}$ in the experimental arm, appearing sev-

TABLE III

Arteriovenous difference of $\mathrm{C}^{14} \mathrm{O}_{2}$ after intra-arterial administration of $4.5 \mu c$ of palmitic acid-1- $C^{14}$

\begin{tabular}{ccccc}
\hline Subject & $\begin{array}{c}\text { Time after } \\
\text { intra-arterial } \\
\text { injection of } \\
\text { palmitic acid- } \\
1-C^{14}\end{array}$ & $\begin{array}{c}\mathrm{C}^{14} \mathrm{O}_{2} \\
\text { activity } \\
\text { in 20 ml } \\
\text { arterial } \\
\text { blood }\end{array}$ & $\begin{array}{c}\mathrm{C}^{14} \mathrm{O}_{2} \\
\text { activity } \\
\text { in 20 ml } \\
\text { blood from } \\
\text { experimental } \\
\text { vein }\end{array}$ & $\begin{array}{c}\mathrm{C}^{14} \mathrm{O}_{2} \\
\text { activity } \\
\text { in 20 ml } \\
\text { blood from } \\
\text { control } \\
\text { vein }\end{array}$ \\
\hline \multirow{3}{*}{ JH } & min & $c p m$ & $c p m$ & $c p m$ \\
& 33 & 23 & 1,840 & 100 \\
& 43 & 100 & 1,027 & 143 \\
RS & 57 & 90 & 756 & 125 \\
& 62 & 242 & 1,182 & 175 \\
& 12 & 75 & 748 & 50 \\
& 25 & 100 & 515 & 120 \\
& 36 & 135 & 415 & 130 \\
& 47 & 170 & 585 & 100 \\
\hline
\end{tabular}

eral minutes after injection of radiopalmitate. This difference was sometimes small initially, but always increased to a peak before a slow decline. The control vein contained levels not very different from those of the arterial blood. The effect of exercise was to increase the concentration of $\mathrm{C}^{14} \mathrm{O}_{2}$ in the venous blood issuing from the experimental arm (see Table IV).

Table $\mathrm{V}$ shows palmitic acid-1- $\mathrm{C}^{14}$ activity in blood from artery and experimental vein. The venous levels of activity exceeded the arterial level, but in all instances declined and approached the arterial concentration.

\section{INTERPRETATION}

The results provide direct evidence that forearm tissues extract FFA from blood and oxidize
TABLE IV

Effect of exercise on arteriovenous difference of $\mathrm{C}^{14} \mathrm{O}_{2}$ after intra-arterial administration of $4.5 \mu \mathrm{c}$ of palmitic acid-1-C $\mathrm{C}^{14}$

\begin{tabular}{|c|c|c|c|c|}
\hline Subject & $\begin{array}{c}\text { Time after } \\
\text { intra-arterial } \\
\text { injection of } \\
\text { palmitic acid- } \\
1-C^{14}\end{array}$ & $\begin{array}{c}\mathrm{C}^{14} \mathrm{O}_{2} \\
\text { activity } \\
\text { in 20 ml } \\
\text { blood }\end{array}$ & $\begin{array}{c}\mathrm{C}^{14 \mathrm{O}_{2}} \\
\text { activity } \\
\text { in } 20 \mathrm{ml} \\
\text { blood from } \\
\text { experimental } \\
\text { vein }\end{array}$ & $\begin{array}{c}\mathrm{C}^{14} \mathrm{O}_{2} \\
\text { activity } \\
\text { in } 20 \mathrm{ml} \\
\text { blood from } \\
\text { control } \\
\text { vein }\end{array}$ \\
\hline RA & $\begin{array}{l}\min \\
12 \\
22 \\
32 \\
42\end{array}$ & $\begin{array}{l}c p m \\
230 \\
190 \\
205 \\
250^{*}\end{array}$ & $\begin{array}{l}c p m \\
1,442 \\
1,350 \\
1,730 \\
2,270^{*}\end{array}$ & $\begin{array}{l}c p m \\
90 \\
218 \\
340 \\
263^{*}\end{array}$ \\
\hline HB & $\begin{array}{l}28 \\
38 \\
48 \\
55\end{array}$ & $\begin{array}{l}305 \\
348 \\
385^{*} \\
395^{*}\end{array}$ & $\begin{array}{c}405 \\
430 \\
2,298^{*} \\
1,475^{*}\end{array}$ & \\
\hline $\mathrm{KL}$ & $\begin{array}{l}22 \\
27 \\
32 \\
42 \\
46\end{array}$ & $\begin{array}{l}215 \\
223 \\
355^{*} \\
295 \\
370^{*}\end{array}$ & $\begin{array}{l}1,720 \\
2,200 \\
4,528 * \\
2,038 \\
2,355^{*}\end{array}$ & \\
\hline SS & $\begin{array}{l}24 \\
29 \\
36 \\
41 \\
46\end{array}$ & $\begin{array}{l}135 \\
125 \\
225^{*} \\
183 \\
238^{*}\end{array}$ & $\begin{array}{l}865 \\
1,145 \\
3,270^{*} \\
1,660 \\
1,935^{*}\end{array}$ & \\
\hline RV & $\begin{array}{l}27 \\
33 \\
37 \\
50 \\
55\end{array}$ & $\begin{array}{l}170 \\
210 \\
248 * \\
270 \\
253^{*}\end{array}$ & $\begin{array}{c}568 \\
690 \\
1,488^{*} \\
623 \\
1,165^{*}\end{array}$ & \\
\hline
\end{tabular}

* Values obtained during exercise.

this FFA to $\mathrm{CO}_{2}$. That muscular exercise did not lower venous $\mathrm{C}^{14} \mathrm{O}_{2}$, but instead increased it in the face of a rise in blood flow provides further evidence that muscle must be a tissue significantly concerned in the process described.

A factor bearing indirectly on the present problem relates to the observed release of fatty acid

TABLE V

Free fatty acid activity in experimental artery and vein at various time intervals after intra-arterial injection of palmitic acid-1-C ${ }^{14}$

\begin{tabular}{|c|c|c|c|}
\hline Subject & $\begin{array}{c}\text { Time after } \\
\text { intra-arterial } \\
\text { injection of } \\
\text { palmitic acid- } \\
1-C^{14}\end{array}$ & $\begin{array}{c}\text { Arterial } \\
\text { FFA activity } \\
\text { per } 20 \mathrm{ml} \\
\text { blood }\end{array}$ & $\begin{array}{l}\text { Venous } \\
\text { FFA activity } \\
\text { per } 20 \mathrm{ml} \\
\text { blood }\end{array}$ \\
\hline & $\min$ & $c p m$ & $c p m$ \\
\hline $\mathrm{AL}$ & $\begin{array}{l}12 \\
22 \\
32 \\
42\end{array}$ & $\begin{array}{r}133 \\
72 \\
61 \\
50\end{array}$ & $\begin{array}{r}453 \\
171 \\
89 \\
89\end{array}$ \\
\hline $\mathrm{CV}$ & $\begin{array}{l}27 \\
42 \\
58\end{array}$ & $\begin{array}{l}66 \\
55 \\
39\end{array}$ & $\begin{array}{r}122 \\
72 \\
55\end{array}$ \\
\hline HS & $\begin{array}{r}6 \\
16 \\
26 \\
36\end{array}$ & $\begin{array}{r}398 \\
89 \\
89 \\
72\end{array}$ & $\begin{array}{r}1,890 \\
271 \\
138 \\
116\end{array}$ \\
\hline $\mathrm{JH}$ & $\begin{array}{l}33 \\
43 \\
57\end{array}$ & $\begin{array}{l}428 \\
258 \\
156\end{array}$ & $\begin{array}{l}740 \\
482 \\
136\end{array}$ \\
\hline
\end{tabular}




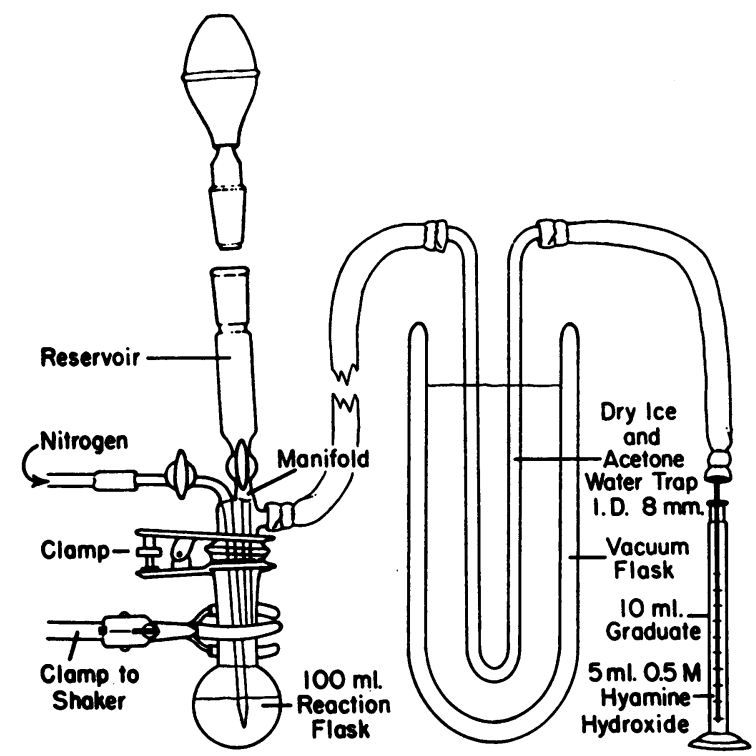

Fig. 1. Schematic drawing of the system for $\mathrm{C}^{14} \mathrm{O}_{2}$ ANALYSIS OF BLOOD.

label from the experimental arm. Compared to the amount of label injected and to the amount of label recovered as $\mathrm{C}^{14} \mathrm{O}_{2}$, the activity of radiopalmitate in venous blood is relatively low during the sampling period and continues to decline. This observation is relevant from two standpoints. First, it indicates that recirculation of labeled fatty acid from the forearm is probably not extensive and that it is a relatively short-lived phenomenon. Second, it is significant in terms of evaluating the problem of contamination of the Hyamine trapping medium by radiopalmitate, or by other non- $\mathrm{CO}_{2}$ activity. Since the recovery studies indicated a maximum of 0.1 per cent contamination, the expected contamination from volatilized radiopalmitate would be calculated to be on the order of 2 , 3 , or fewer cpm. Furthermore, although the venous levels of radiopalmitate activity in the experimental arm were higher than the arterial levels, the measured $\mathrm{C}^{14} \mathrm{O}_{2}$ level was overwhelmingly in excess of the arterial level of $\mathrm{C}^{14} \mathrm{O}_{2}$. It is noteworthy that in two studies the measured arteriovenous difference of $\mathrm{C}^{14} \mathrm{O}_{2}$ was very small at a time when recirculating venous radiopalmitate would be expected to be relatively high.

In addition to the items discussed, it is apparent that liberation of $\mathrm{C}^{14} \mathrm{O}_{2}$ from the forearm proceeds at a relatively slow rate which also declines slowly. One might venture to note from a casual observa- tion of the results of this study that many hours would be required to eliminate the radioactivity by excretion as $\mathrm{C}^{14} \mathrm{O}_{2}$, although initially radiopalmitate must have been very rapidly removed from the circulation. It is in fact very likely that $\mathrm{C}^{14} \mathrm{O}_{2}$ elimination from the forearm probably parallels fairly closely total body $\mathrm{C}^{14} \mathrm{O}_{2}$ elimination as measured by Fredrickson and Gordon (3). A comparison of the arteriovenous difference of $\mathrm{C}^{14} \mathrm{O}_{2}$ in Tables III and IV and radiopalmitate released by forearm recorded in Table $\mathrm{V}$ indicates that the rate of radiopalmitate release (and therefore its availability for oxidation by other tissues) becomes trivial in comparison to $\mathrm{C}^{14} \mathrm{O}_{2}$ production by the forearm. It is therefore unlikely that the slow elimination of radioactivity in expired air is related to recirculation of radiopalmitate.

The following concept is suggested as an explanation for the observation that body and forearm $\mathrm{C}^{14} \mathrm{O}_{2}$ excretion proceeds at a relatively slow rate. Assuming a forearm plasma flow of $10 \mathrm{ml}$ per minute (11), an arterial free acid concentration of $500 \mu$ moles per $L(1,2)$, and a 30 per cent uptake (7), the amount of FFA taken up by the forearm would be $1.5 \mu$ moles per minute. The forearm fatty acid pool is then uniformly labeled with, let us say, $2.4 \times 10^{6} \mathrm{dpm}$ of radiopalmitate. Assume that the rate of uptake, $1.5 \mu$ moles per minute, also represents the rate of oxidation in a steady state, and that $4,000 \mathrm{dpm}$ of $\mathrm{C}^{14} \mathrm{O}_{2}$ are issuing from the forearm per minute. Initially this rate would be about 0.17 per cent oxidation per minute of the radiopalmitate taken up by the forearm and is equivalent to the $1.5 \mu$ moles assumed to be burned per minute. A rough approximation of the size of the forearm fatty acid pool then would be $\left(2.4 \times 10^{6}\right)(1.5) / 4,000=900 \mu$ moles FA, or approximately $230 \mathrm{mg}$. It can be seen that the forearm fatty acid pool does not need to be very large in order to account for the apparent slow release of labeled $\mathrm{C}^{14} \mathrm{O}_{2}$ and relatively large uptake of circulatory free fatty acid.

The complete oxidation of $1.5 \mu$ moles per minute of palmitic acid by the forearm would require $34.5 \mu$ moles of oxygen per minute. This order of magnitude would appear to fit quite well with the known oxygen consumption of resting forearm (11) and with the fraction of this oxygen consumption apparently relegated to nonglucose utilization. 
SUM MARY

Palmitic acid-1- $\mathrm{C}^{14}$ was injected into the brachial artery of normal fasting subjects. Radiopalmitate and $\mathrm{C}^{14} \mathrm{O}_{2}$ activity was measured in arterial blood and in venous blood of experimental and control forearm.

After discontinuance of radiopalmitate infusion, a large negative $\mathrm{C}^{14} \mathrm{O}_{2}$ difference was observed in the experimental (but not in the control) forearm. Simultaneously, a much smaller but still negative arteriovenous difference of radiopalmitate was observed.

The data provide direct evidence for the oxidation of fatty acids by peripheral tissues in man.

\section{ACKNOWLEDGMENT}

The authors would like to thank Mrs. Marie Dowdee, Mrs. Anna Ferguson, Mrs. Sadie S. Goodman, Miss Corinna Thomas, Miss Helen L. Hilderman, Mrs. Gray Long, Mrs. Gitta Jackson, Mrs. Maurine Jones, and Mr. Albert Eaton for their invaluable assistance. We are especially indebted to Dr. Noble J. David for his assistance in the plethysmographic determinations.

\section{REFERENCES}

1. Dole, V. P. A relation between non-esterified fatty acids in plasma and the metabolism of glucose. J. clin. Invest. 1956, 35, 150.

2. Gordon, R. S., Jr. Unesterified fatty acid in human blood plasma. II. The transport function of unesterified fatty acid. J. clin. Invest. 1957, 36, 810.
3. Fredrickson, D. S., and Gordon, R. S., Jr. The metabolism of albumin-bound $\mathrm{C}^{14}$-labeled unesterified fatty acids in normal human subjects. J. clin. Invest. 1958, 37, 1504.

4. Friedberg, S. J., Harlan, W. R., Jr., Trout, D. L., and Estes, E. H., Jr. The effect of exercise on the concentration and turnover of plasma nonesterified fatty acids. J. clin. Invest. 1960, 39, 215.

5. Carlson, L. A., and Pernow, B. Studies on blood lipids during exercise. I. Arterial and venous plasma concentrations of unesterified fatty acids. J. Lab. clin. Med. 1959, 53, 833.

6. Basu, A., Passmore, R., and Strong, J. A. The effect of exercise on the level of non-esterified fatty acids in the blood. Quart. J. exp. Physiol. 1960, 45, 312.

7. Friedberg, S. J., Klein, R. F., Trout, D. L., Bogdonoff, M. D., and Estes, E. H., Jr. The characteristics of the peripheral transport of $\mathrm{C}^{14}$-labeled palmitic acid. J. clin. Invest. 1960, 39, 1511.

8. Bragdon, J. H., and Gordon, R. S., Jr. Tissue distribution of $\mathrm{C}^{14}$ after the intravenous injection of labeled chylomicrons and unesterified fatty acids in the rat. J. clin. Invest. 1958, 37, 574.

9. Laurell, S. Recycling of intravenously injected palmitic acid-1-C $\mathrm{C}^{16}$ as esterified fatty acid in the plasma of rats and turnover rate of plasma triglycerides. Acta physiol. scand. 1959, 47, 218.

10. Fredrickson, D. S., and Ono, K. An improved technique for assay of $\mathrm{C}^{14} \mathrm{O}_{2}$ in expired air using the liquid scintillator counter. J. Lab. clin. Med. 1958, $51,147$.

11. Andres, R., Cader, G., and Zierler, K. L. The quantitatively minor role of carbohydrate in oxidative metabolism by skeletal muscle in intact man in the basal state. Measurements of oxygen and glucose uptake and carbon dioxide and lactate production in the forearm. J. clin. Invest. 1956, 35, 671.

\section{SPECIAL NOTICE TO SUBSCRIBERS}

Post Offices will no longer forward the Journal when you move.

Please notify The Journal of Clinical Investigation, Business

Office, 333 Cedar Street, New Haven 11, Conn., at once when you have a change of address, and do not omit the zone number if there is one. 